\title{
Institutional barriers to successful innovations: Perceptions of rural farmers and key stakeholders in southwest Nigeria
}

Oluwaseun Kolade ${ }^{1 *}$, Trudy Harpham² and Gaim Kibreab ${ }^{2}$

1. Weeks Centre for Social and Policy Research, London South Bank University, London, UK

2. Department of Social Sciences, London South Bank University, London, UK

*Corresponding author, email: kolades@1sbu.ac.uk

Citation: Oluwaseun Kolade, Trudy Harpham \& Gaim Kibreab (2014) Institutional barriers to successful innovations: Perceptions of rural farmers and key stakeholders in southwest Nigeria, African Journal of Science, Technology, Innovation and Development, 6:4, 339-353, DOI: 10.1080/20421338.2014.966039

Abstract: Diffusion studies in sub-Saharan Africa have typically focused on the impact of traditional adoption factors on uptake of technological innovations. This study draws on semi-structured interviews of rural farmers and in-depth interviews of stakeholders in southwest Nigeria to examine the impact of institutional factors on the success of technological innovations. The findings indicate that government policies, markets, financial institutions, infrastructure and other institutional conditions play significant role on the success of technological innovations. A successful innovation package should integrate institutional reforms with promotion of innovative inputs, and vibrant farmers' cooperatives can be at the heart of such agrarian reform.

Keywords: Innovations, rural development, institutions, cooperatives, sub-Saharan Africa, Nigeria.

\section{Introduction}

Innovation is often conceived purely or mainly in terms of development and diffusion of new technologies for improved productivity and development. However, a more comprehensive conception of innovation incorporates technological aspects - new products and services, as well as non-technological aspects, like institutional and organisational innovations (Ruttan 2001, Fan, et al. 2009, Doner 2010). Both of these aspects are essential for the success of innovations in the context of national development, and should command adequate attention of diffusion researchers, policy makers and other organisation involved in the development and execution of development intervention programmes.

\section{Innovations in institutional contexts}

\section{The research question}

This article addressed the principal question: Do institutional factors contribute significantly as technological products towards the success of innovations among rural farmers in southwest Nigeria? In other words, for example, how much do institutional conditions like access to the market play a significant role in the diffusion, spread and profitability of, say, high yield maize varieties among small-scale farmers in southwest Nigeria? Furthermore, how and to what extent do, and can, cooperatives positively harness or influence institutional conditions for successful innovations? Here, the success of the innovations is defined with respect to two key criteria: 1) their effectiveness in improving agricultural productivity, in terms of quantity and quality of farm outputs; 2) their function in terms of improving profit and income 
of farmers. Both of these criteria define the impact of innovations on the nation's food security and rural development.

It has been observed that that new agricultural technologies offer potential benefits in terms of increased produc- tivity and profit for farmers, but, more often than not in developing countries, these innovations are not taken up quickly enough or widely enough to ensure the realisation of full benefits. Several factors have been identified by diffusion scholars for low levels of uptake of new technologies. There are concerns associated with the rate and speed of adoption, including economic constraints, technical expertise, technology characteristics, and ownership and risk. With respect to the impact of economic constraints on small-scale farmers in developing countries, there is significant attention in the literature on the influence of household wealth (Langyintuo and Mungoma 2008, Marenya and Barnet 2007), cost constraints associated with availability of labour (White et al. 2005), extra cost associated with technologies that require purchased external outputs (Moser and Barrett 2003), and the impact of non-farm income (Langyintuo and Mungoma 2008, Marenya and Barrett 2007).

Some scholars have suggested that traditional barriers to uptake of innovations highlighted in the foregoing are linked to, or directly influenced by, a number of institutional factors (Doner 2010, Fan et al. 2009). Among other things, it would appear that the role of governments in overseeing provision of essential infrastructure, accessibility and effectiveness of financial institutions, and the dynamics of market competition, locally and internationally, can play significant roles in the effectiveness and success of innovative inputs. 


\section{Conceptual framework}

Sociologists have examined the differences between the dynamics of groups and individuals, with respect to decision making, commitment, performance, effective- ness, and risk avoidance, among others. It has been suggested that, often times, groups foster better commitment, goal attainment and greater satisfaction than do individuals (Hinsz and Nickell 2004), and this is often associated with greater social capital and the better capacity of groups to promote social learning and intellectual capital (Johnson 2007, Hartley and Johnson 2013). This narrative is relevant to understanding why cooperatives are, in the context of this study, considered more secure than individual farmers.

Adoption studies in sub-Saharan Africa, and Nigeria in particular, have focused mainly on the impact of traditional adoption factors, with comparatively little attention on the role of institutions. Where the impacts of institutions have been examined, scholars have almost exclusively adopted a quantitative method of investigation. This approach generally fails to capture the nuances and complexities of the issues surrounding the performance and effectiveness of institutions, including the perception of farmers and key stakeholders. This study contributes to this significant gap in knowledge by employing a qualitative approach to examine the impact of institutional factors on successful uptake of technological innovations among small-scale rural farmers in southwest Nigeria.

Figure 1 below summarises the interactions and relationships between technological innovations, institutional factors, cooperatives and farmers' socio- economic characteristics. Innovation is conceived in two dimensions - of technical products (inputs and machineries) and institutional factors. Farmers' socio- economic characteristics influence, and are in turn affected by, these two dimensions of innovations. For example, a farmers' income level is positively related to their ability to procure inputs and hire machinery. On the other hand, access to loans from micro-credit institutions improves farmers' ability to procure innovative inputs. The cooperative is a strategic centre of these intertwined relationships, affecting and affected by various institutional factors, as well as farmers' socio-economic characteristics. The nuances and details of these relation- ships will be explored further in the following analyses.

In most developing countries, one of the key challenges to diffusion of innovation among small-holder farmers in particular and small-scale enterprises (SMEs) in general, is lack of, or very limited access to credit. It has been observed that commercial banks are biased towards big corporations in their lending and offers of competitive interest rates, while interest rates remain very high for SMEs, which are regarded by banks as high risk borrowers, with insufficient assets and high vulnerability to market fluctuations (Warner 2001). 
Innovations

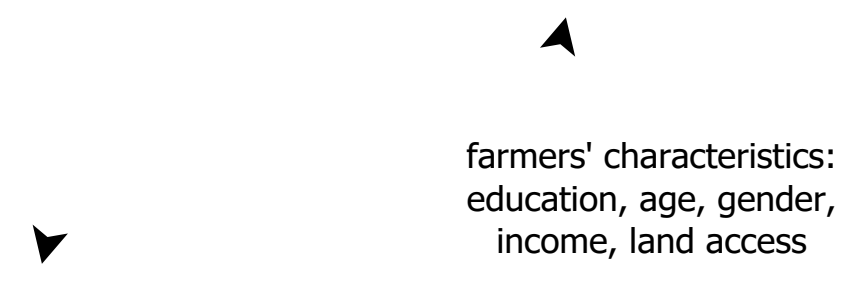

Tech Products

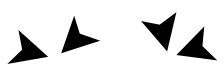

Inputs:

HY Maize; HY Cassava;

Fertilizer; Pesticides.

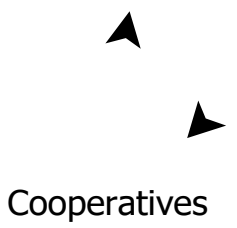

Cooperatives
Institutional reforms:

Infrastructures;

micro-credit;

markets, land tenure.

Figure 1: Technologies, institutions and cooperatives

Machineries:

Tractor combines;

Irrigation technology. 
Access to affordable physical infrastructure has been identified as 'a major, if not the major, component of competitiveness in the agricultural value chain (FAO 2008, pp i). In this context, transportation networks, energy infrastructures, water supply and communication infrastructures are important for on-farm production, efficient trading and exchange, and movement of agricultural produce (FAO 2008). These infrastructural needs are principal responsibilities of national and local governments, who sometimes partner with private firms and organisations. The Nigerian experience has shown, with respect to the entire development agenda, that lack of power supply constitutes a major hindrance to the adoption and operation of new technologies. It is often the case, and this is especially so for smallscale farms and businesses, that potential profit is usually eliminated by the significantly higher cost incurred in securing alternative power supplies from, say, generators (Ayodele et al. 2013, Oyedepo 2012). By the same token, the cost of transport from rural areas, where the roads are in derelict conditions, is usually several times much more than within major cities, and this in turn impacts highly on the cost of farm produce, as well as constituting a major disincentive to the adoption of innovation and up-scaling of farm production (IFAD 2012, Kassali et al. 2012, Christopher et al. 2010, Bah et al. 2003).

\section{Method}

\section{Study locations}

The survey locations for this study were selected using purposive sampling. Thus, southwest Nigeria was chosen out of the six geopolitical zones in Nigeria. Comprising of six states, the southwest forms the bulk of the pre-independ- ence western region, and it is populated mostly by the Yoruba ethnic group. Within the Southwest Zone, Oyo State was selected. Oyo State is significant in the history of agricultural policies and reforms in Nigeria. Ibadan city, one of the biggest cities in Africa and the current capital city of Oyo State, was also the regional headquarters of the old Western Region. The city was the policy and administrative headquarters of the hugely successful agrarian reform of the regional government of the former Western Region, when Nigeria was still a confederacy.

\section{Sampling}

For this study, four out of 33 local governments in Oyo State were chosen. The main criteria used for purposive sampling of survey locations were: 1) total arable land available for farming, as most local governments are highly dense areas in big cities; 2) intensity of agricultural activities; and 3) location of the states' farm settlements. Thus the focus was on rural areas of the state where there is more land available for agriculture and more people are engaged in farming. Moreover, all the farm settlements are located in the rural areas of the state. These farm settlements, with more direct government involvements, were examined along with other cooperatives to examine the peculiar character, opportunities and challenges of the system.

Altogether, 25 villages were visited and 240 farmers- both cooperative and non-cooperative members - were interviewed according to semi-structured interview schedules. In order to examine relationships and differ- ences associated with gender, about every third respondent was a woman. Also, about a fifth of the respondents were farm settlers. Finally, 13 key stakeholders were selected for in-depth interviews, according to the following categories:

\section{Bankers:}

Principal Officer, Bank of Agriculture, Southwest (Nigeria) Zone, Ibadan, Nigeria

Loans Officer, Bank of Agriculture, Southwest Zone, Ibadan

Business Development Manager, Union Bank, Dugbe, Ibadan.

Government officials:

Special Advisor to the Governor on agriculture, Oyo State Ministry of Agriculture and Water Resources, Ibadan Director, Crops and Farm Settlements, Oyo State Ministry of Agriculture, Ibadan 


\author{
Extension agents: \\ Principal Officer, Oyo State Agricultural Development Agency, Ibadan, Nigeria (OYSADEP) \\ Deputy Principal Officer, OYSADEP. \\ Research institutes:
}

Cassava expert, Institute of Tropical Agriculture (IITA), Ibadan, Nigeria.

Maize expert, IITA

Agric economist, Institute of Agricultural Research and Training (IARandT), Ibadan, Nigeria.

Agro dealers:

Chairman, Oyo State Agro-dealers Association, Dugbe, Ibadan

Executive Secretary, Oyo State Agro-dealers Association, Dugbe, Ibadan

Director, Amens Agro Dealers Ltd, Mokola, Ibadan.

\title{
Method of analysis
}

Information obtained from the semi-structured interviews of farmers and unstructured interviews of key stakeholders were transcribed in English and fed in fed into the sources section of Nvivo 10. In the Nvivo 10 software, there are two types of sources: internals and externals. In this investigation, no external sources were used. The transcripts of semistructured interviews of farmers and in-depth interviews of key stakeholders were put into separate sub-folders under 'internals' sources. Recurring themes and trends in respondents' interviews were coded and entered using nodes, for ease of retrieval for subsequent discussions of key themes. There are two types of nodes: child nodes and parent nodes. Child nodes were used at the initial stage of the essentially iterative coding process, and nodes with similar themes were subsequently grouped together under appropriate parent nodes. Thus, for example, in this investigation, child nodes titled "cooperative access to bank loans", "loan recovery", and "loan security" were all grouped together under the parent node "access to credit". Required sections and paragraphs for analysis were retrieved either directly through the nodes, or using the Queries menu in the application.

\section{Discussion}

\section{The challenge of inadequate funds}

Access to necessary funds is an essential requirement for farmers' uptake of technological innovations. Farmers require funds to, among other things, procure inputs, buy or hire machineries, service and maintain equipment, pay for labour, expand production, and mitigate risks. The funds come in terms of farmers' income - farm and non-farm income savings, loans from friends or cooperatives, and credit from banks. Small-scale farmers are typically poor with very limited access to funds in terms of income. Thus, in this section, attention is focused on the challenges and opportunities associated with other means of accessing funds available to farmers other than personal income, with specific reference to loans from friends and/ or cooperatives, loan security and other conditions for government and bank loans, and problems associated with loan repayments.

\section{Loans from friends/cooperatives}

Farmers sometimes form ad hoc savings groups where members take turns taking the bulk of contributions, or, as contributing members of formal cooperatives, obtain loans with minimal interest rates from the cooperative purse. One of the key challenges associated with these types of arrangements is the level of trust and commitment needed for repayment of loans and maintenance of the loan cycle for the benefit of contributing members. One member of a farm settlement laments:

We farm settlers presently do not contribute or run a credit society, we tried it before and it failed; some members betrayed the rest of us when times are hard, running off with the loans, never to return. There was a man in particular that fled up north.

Experiences like this, recounted by many of the respondents, undermine the capacity of the cooperative to mobilise loans by means of members' contributions. It is also clear that the sustainability of the cooperative loan arrangement is associated with the ability of the cooperatives, and individual members, to mitigate or overcome risks. The respondent 
above spoke about 'when times are hard', usually a reference to climatic and environmental 
conditions leading to crop failures or low harvests, or adverse market conditions leading to big losses in farm income, which in turn makes it difficult or impossible for farmers to repay loans. It is suggested that farmers in cooperatives sometimes tend to undertake riskier activi- ties and borrow more from the cooperative purse because the down-side risk is shared by all members. In the event of crop failure or any other hazard, such members find it harder to repay loans (Ayanda and Ogunsekan 2012).

The challenges of the market environment will be examined in greater detail, but it appears that cooperative societies need continuing support in terms of training for risk control and better management of cooperative funds. The democratic structure of the cooperative, good in itself, often means that elected leaders are not necessarily the best in terms of knowledge and expertise in financial management, exposing the cooperative to higher risk than usual. With continuous training and support, this knowledge deficit can be mitigated, and the cooperative better positioned to manage risks and minimise incidences of default among members.

\section{Administration of government and bank loans}

In Nigeria, the two types of banks involved in provision of loans for farmers are the publicly owned Bank of Agriculture, and various commercial banks mandated by the central bank, in addition to managing dedicated funds from federal government, to commit a certain percentage of their capital as agro-credit for small-scale farmers. According to a senior official at the Bank of Agriculture: We have six zones in Nigeria, in each of the six geopolitical zones. In southwest, we have 39 branches/

outlets, an average of five to six branches in each state.

The geographical spread and limited number of the branches of this Bank of Agriculture - typically located in big towns and cities - is such that it is more difficult for rural farmers in remote areas to access the services, and this is another compelling argument for viability of group, rather than individual, access. In general, the ratio of rural branches to total branches of formal credit institutions is quite low (Badiru 2010).

The major problem identified by both the government owned banks and commercial bank is the challenge of loan recovery:

The last one we did, Oyo State trust fun, Central Bank of Nigeria (CBN) contributed 25\%, the bank contributed $25 \%$, and the farmers contribute $25 \%$ in their savings account. This is for non-salaried farmers. Unfortunately they didn't do well. At the end of the day, we were unable to recover the loans, since 2009 (Business Development Manager, Union Bank, Dugbe, Ibadan).

Our farmers can become really difficult after they collect loans. Before they borrow they act like angels (Principal Manager, Bank of Agriculture, Ibadan, Southwest Zone).

As a result of this perennial problem of loan recovery, the amount of funds available to be recycled for new loan applicants, for the Bank of Agriculture in particular, is 
severely depleted, while the commercial banks have either stopped, or drastically reduced, the number of loans given out to non-salaried farmers. Moreover, it is alleged that government has stopped providing additional funds for the Bank of Agriculture, at least for the past few years:

The demand for loans has increased over the years, but the allocation has not been increasing according to demand. For the past few years, the bank has not received any additional funds from the federal government (Principal Manager, Bank of Agriculture, Ibadan, Southwest Zone).

It appears the government has not been able to grapple with this challenge, and is unwilling to commit new funds to a system of credit disbursement that has been unsustain- able for many years and needs to be reformed with a well coordinated, comprehensive strategy.

\section{Loan securities and interest rates}

In an effort to deal with the problem of defaults and loan recovery, banks have set out more stringent conditions for farmers applying for loans. For commercial banks, the focus is on cash inflows and other collateral:

We have different types of loans under agric. We have Global limit, for this type there must be a salary inflow, so their salary is the collateral. So this is mostly for civil servants and other salaried workers engaged in farming on a part-time basis ... We consider securities like property. I know these are poor farmers, but we have to be very careful as banks to get adequate securities. In the past we have had experiences where people show us false farms in order to get the money, and then disappear, so we need to get securities (Business Development Manager, Union Bank, Dugbe, Ibadan).

The Bank of Agriculture, as it is public-owned, is obliged to give equal consideration to salaried and non-salaried applicants, so they have focused more on additional processes for authenticating the farm holdings of applicants, and getting guarantors for each applicant:

Our conditions are as follows: anyone applying for small-scale loan is to present two people as guarantors. Those guarantors would be people with regular sources of income. Regular income is not necessarily in terms of salary. We don't insist on salaried workers, but over the years, we have found that oftentimes the borrowers are unable to pay, and then guarantors are also unable to pay, so in recent years we prefer to have at least one of the guarantors as salaried worker. We don't make it mandatory, but it's desirable ...

Last year in Osun State (neighbouring state) we have a group of farmers saying they have 50 acres of land. When they take you to a village and show you a big area of land, and the village elders don't disagree, how can we contradict them or know they are lying? Eventually we found that the land size claimed by these farmers is not true. So government has to begin using GPS to cross-check, and it revealed a lot more in terms of false claims. But using GPS is a laborious process. Osun State used to have one GPS, now they have two, to try to reduce the occurrence of false land claims (Principal Manager, Bank of Agriculture, Ibadan, Southwest Zone).

The conditions outlined by the commercial bank above make it almost impossible for poor rural farmers to access 
the loans, as they are non-salaried workers, their farm holdings are held on rentals or community leases, and they cannot use their village mud houses or bamboo huts as collateral. Conversely, the conditions set by the Bank of Agriculture are less stringent, but nevertheless present different kinds of problems, especially in regard to the requirements for guarantors. First, many farmers find it difficult to find guarantors willing to commit themselves on their behalf. Where they are able to get guarantors, some of the guarantors often set personal conditions that part of the loan obtained by farmers is given to them. For this latter group, the cash they get at the end of the process is significantly depleted, and this, added to the burden of the interests on the loans, makes it much more difficult for the farmers to repay. Other studies have similarly identified collateral, lack of bank accounts, the complex process of loans from commercial banks, and loan defaults, as major factors limiting credit access of poor rural farmers (Okojie et al. 2010, Food and Fertilizer Technology Centre 2004, Adejobi and Atobatele 2008).

The interest rates set by the bank of agriculture is, as expected, lower than those set by commercial banks, except where commercial banks are disbursing dedicated funds provided by the federal government:

The interest rate for small-scale farmers is $12 \%$ per annum. Small-scale farmers are not categorised according to how much land, but according to how much money they obtain as loans. So we define small-scale farmers as those who obtain up to N 250000 (1 533 USD). That's our practical definition of small-scale farmers (Principal Manager, Bank of Agriculture, Ibadan, Southwest Zone).

There is also 'seed buy back' initiative. People were given opportunities to borrow from the bank to produce seeds that government can buy back. The rate for this is $7 \%$, but to get this we need securities. Many of those who take the loans use the money for non-farming purposes. This is one of the problems we have. The Oyo State trust fund was for nonsalaried farmers. The interest for that is $18 \%$, but up till today we haven't recovered loans from the 10 farmers we gave the loans to (Business Development Manager, Union Bank, Dugbe, Ibadan).

Some of the farmers have contradicted these figures supplied by the banks, quoting as high as $32 \%$ interest rate for loans obtained from commercial banks and 17\% for the Bank of Agriculture. Others have complained about the inadequate time frame allowed for loan repayments:

The challenge faced is the inadequate span of government loans. I obtained a loan last August but it was not up to a year after that when they demanded a repayment of the loan. We are not given enough time to repay loans and that is a huge problem, you know (Farmer 2).

In the light of the foregoing challenges and difficulties associated with loan access, one of the main approaches encouraged by banks is the disbursement of loans through farmers' cooperatives:

The federal government prefers dealing with groups rather than individuals. It is easier to deal with groups. For one, it is easier for the banks to chase up the key leaders of the cooperatives, like chairman, secretary and cooperatives.

In addition, federal government want the farmers to unite together. For example, the current collaboration we have with Osun State, the state government prefer to deal with cooperatives rather than individuals. Individuals still get the loans, but through their membership of the cooperatives. Sometimes, a cooperative can decide to use the loan for a group farming project (Principal Manager, Bank of Agriculture, Ibadan, Southwest Zone).

We will prefer to deal with cooperatives because there will be security in place, but at the moment we have not had requests for loans from cooperatives (Business Development Manager, Union Bank, Dugbe, Ibadan).

From the standpoint of the banks, the cooperative arrangement presents a potentially effective platform to mitigate the problem of securities and loan recovery. The cooperative is, for example, typically in a stronger position to present jointly owned property or savings as collateral on behalf of all members. Also, transaction costs for individual farmers are 
significantly reduced as banks interact with cooperative leaders, who then take responsibility for distribution and recovery of the loans. Thus, the sharing of liability, and of benefits, represents a distinct advantage for farmers who are members of the cooperative, as this farmer affirms:

The benefit of membership of the cooperative is the relative ease with which government grants a loan to a group rather than to an individual. In groups of at least 10, the loan is handed over to the Chairman, Secretary and Treasurer who are held responsible for both disbursement and repayment (Farmer 10),

This arrangement through a cooperative does not, however, solve all the problems:

You can't really force people into cooperatives. For example, when I was in the east (southeast Nigeria), farmers don't seem to get involved a lot in cooperatives. There was a time the federal government cancelled the ideas of individuals coming directly to the bank, but it didn't really work because then various people of different characters just started forming fake cooperatives so they can obtain loans, and then they disappear (Principal manager, Bank of Agriculture, Ibadan, Southwest Zone).

Aside from the obvious fact, stated above by the bank manager, that cooperative membership is voluntary, the advent of 'fake cooperatives' represents a peculiar problem that may be more difficult to handle, especially if the 'fake cooperatives' began as fully registered bodies with the relevant government department.

As the following sections show, farmers are faced with a multi-faceted challenge in their bid to adopt innovations for increased productivity and profit, and access to credit is but one dimension of the problem. The multi-dimensional challenge requires a multi-pronged, comprehensive approach; product (input and machinery) innovation should be married with institutional innovation. One area that requires priority attention and innovation is improving the competiveness of small-scale farmers in a free market.

\section{Value addition and market competiveness}

In recent years, there has been more attention given by scholars of diffusion of innovation and rural develop- ment to the importance of value addition in the develop- ment and evolution of agricultural inputs and produce (Sanni et al. 2005, Fleming 2012). The value-added chain for agricultural products consists of activities at the design state of the product, as well as processing of harvested produce to enhance their market values.

There is thus a close connection between active engagements in the value-added chain and competitiveness of smallscale, rural farmers, which is in turn linked with increased profit required for beneficial uptake of innova- tions. This competitiveness is impacted by three main factors: the quality and depth of farmers' knowledge about innovative inputs (Herbel et al. 2012), availability and efficient deployment of processing facilities for enhancing the value of raw farm outputs (Sanni et al. 2005, Fleming 2012), and the knowledge and capacity to access domestic and foreign markets (Kawa and Kaitira 2007).

Value addition in the design of innovative inputs Scientists and experts at various agricultural research institutes have traditionally been engaged in research activities to fortify seeds and other inputs against streaks of viral and pest attacks as well as other unfavour- able climatic and other natural conditions. Thus, the earliest varieties of cassava and maize developed at the International Institute of Tropical Agriculture (IITA) and agricultural research institutes in sub-Saharan Africa were fortified so that they are multiple-pest resistant, in addition to breeding them "for high yield, for root quality, and for ease of peeling" (Cassava expert, IITA).

In recent years, there has been more focus on value addition by means of improving the aesthetic quality and nutritional value of agro inputs. At the International Institute of Tropical Agriculture, Ibadan, Nigeria, this includes injecting new cassava varieties with vitamins, maize varieties with protein and vitamins, and developing yellow-fleshed cassava and maize in response to popular domestic demand:

We breed to increase the nutritional value of the cassava. Recently the Federal Government released three of our breeds, which are bio-fortified. We call them yellow fleshed cassava, released in 2011. In the mid-west you'll find that people prefer 
yellow gari, because they add palm oil to it, but now we are breeding yellow fleshed so it won't be necessary to add oil ... Nestlé is funding some of our varieties, as they use starch to make their indomie. The yellow fleshed cassava varieties we released was funded by Harvest Plus, based in Seattle, Columbia. Similar ideas were followed in the development of yellow grained maize, with vitamin A, also iron bean in Uganda, and zinc millet in other countries (Cassava expert, IITA).

Just two months ago, we have hybrid maize 1, 2, 3 and 4. Among these we have protein based maize varieties. Also in the last five years, IITA has been working on improving 
vitamin A content in yellow maize, so these new varieties have high levels of Vitamin A (Maize expert, IITA).

As the experts' comments above show, improvement of nutritional value is at the heart of recent efforts by agricultural research institutes to develop new inputs, and big food companies like Nestlé are actively involved, by means of sponsorships for products tailored to their requirements, like indomie made from starch obtained from cassava.

Although a good number of rural farmers have adopted innovative inputs like high yielding cassava and maize varieties, the vast majority are not sufficiently informed to make the distinctions between various new varieties of cassava and maize, especially with regard to the peculiarities of each variety in terms of nutritional fortifications and potential uses in raw and processed states. Indeed, many of the respondents simply refer to these innovative inputs as "IITA cassava" and "IITA maize".

For example, many farmers are not sufficiently aware of the different requirements and outcomes for cultivating different varieties of maize:

We produce open pollinated maize varieties, which means farmers can save/store their own seeds, for up to three years. We also have different types of hybrids, which yield much better than open pollinated varieties. For hybrids, farmers can't save the seeds, because if they use saved seeds the following year, there will lots of segregation and significant reductions in output. They have to buy every year from seed companies. Farmers have a choice to use either hybrids and open pollinated. Hybrids can't be open pollinated because they come from two or three parents. Hybrids typically yield up to 10 tons per hectare, but they also require more fertilizers, whereas the maximum you can get from open pollinated varieties is 6 tons per hectare (Maize scientist, IITA).

Thus, farmers who save their hybrid maize seeds will probably be confused and disappointed in the event of significant drop in harvest, and may be tempted to abandon the innovation altogether. Similarly, farmers who impatiently harvest their cassava produce before the minimum recommended time are unlikely to reap the optimum benefit on value added for the innovative varieties, as this expert reveals:

Our varieties are typically designed to be matured in one year, but sometimes farmers harvest these early, as early as seven months. When they compare with the traditional ones that they keep for two years, they see that it's even better. Even at that, we advise them not to harvest them before nine months. But you know our farmers, they sometimes ignore this because they are impatient to harvest and sell to make money (Cassava scientist, IITA)

Thus, the roles of extension service providers and agro dealers are all the more important in the value-added chain, ensuring farmers have the right information about each input, and the know-how to plan according to the design and prescriptions of technology developers for optimum output. This will be explored in a subsequent section 


\section{Availability and use of processing facilities}

In Nigeria, the vast majority of rural farmers produce raw goods. In addition to the fact of comparatively low value of raw agricultural produce, these small-scale farmers are also at a distinct disadvantage with regard to storage of raw produce, especially at bumper harvest periods when the market is saturated and prices low.

Processing significantly improves the market value of agricultural products, compared with their raw states. In Nigeria, there are processing methods for processing cassava into various products like gari, which accounts for about $70 \%$ of processed cassava in Nigeria, cassava flour, chips, and, more recently, cassava bread (Knipscheer et al. 2007). Similarly, corn can be processed into corn flour, ogi and custard (Abdulrahaman and Kolawole 2006). However, the majority of rural farmers do not process their produce, due to various factors ranging from economies of scale, availability of processing equipment and machinery, and the logistics of time required in addition to their farming activities. Thus, farmers often find themselves at the mercy of middlemen:

The middlemen charge a percentage (commission) on the produce and that itself is some form of inducement to sell the goods, hence we really cannot rule out being cheated. In addition, we lack a means of preserving our produce (Farmer 97).

To offset this difficulty, some government agencies have been involved in 'organising farmers into producer groups linked with big food companies, or owning processing units themselves' (Agric economist, Institute of Agricultural Research and Training, Ibadan). Thus, for this initiative to work, small-scale farmers need to organise themselves into groups. The cooperative structure fulfils the basic criteria.

\section{Access to domestic and international market}

The competitiveness of smallholder farmers in the free market is essential for their goal of optimising profit in sales of their farm outputs, either in raw or processed state. The awareness of rural farmers is typically limited to the traditional food-oriented domestic market (Knipscheer et al. 2007). They have little or no information about new emerging markets, domestically and internationally, for industrially processed goods using raw agricultural products, like cassava industrially processed into chips, food grade ethanol and starch. This lack of awareness represents a distinct disadvantage in a fiercely competitive market environment. Moreover, unless they come together in groups, individual farmers find themselves in a very weak and vulnerable position in the market, as the following comments reveal:

The middlemen are cheating us big time but there is nothing we can do about it. Their prices are arbitrary and the urgent need for money oftentimes makes it difficult us as settlers to stick together collectively to a definite plan on the schedule for the marketing of our produce and on price regulations (Farmer 90).

There is no way the middlemen will not cheat us because we have nowhere else to take our produce apart from the market. We do not really have a say on the price, and taking the produce back home is hardly an option (Farmer 91).

Truly, the middlemen are ripping off us heavily, for instance a sack of fresh maize that goes for N2 000 (12USD) today may be said to sell for N1 000 (6USD) the next day - unpredictable price fluctuations. Moreover, Eleekara market happens to be the only market where we all sell our farm produce (Farmer 93).

Marketing tops the list of our challenges. Personal consumption of our produce is, in fact, the only profit we have. Farmers can boast of profit only once every four years. At the beginning of this year a truckload of maize sold for N100 000 (613USD) while a tractor-full went for N70 000 (429USD) but currently, that same quantity goes for just N20 000 (123 


\section{USD)! (Farmer 1).}

There are three key recognitions from the farmers' comments highlighted above: the need to come together and forge a united front as a group; the need to expand links and access to the market, highlighted by Farmer 91's frustration that there was only one market (Eleekara) where he could sell his produce; and the need for stability and control of market prices of goods.

From the foregoing, the development of bonding, bridging and linking social capital is essential for farmers' viability and adaptability in a competitive and continu- ally changing market environment. By coming together in formal cooperatives, for example, farmers are able to build trust, enhance cohesion and solidarity, and develop better understanding of shared problems and difficulties, as well as gain better awareness of market opportunities. By bridging relations with similar farmer groups and coopera- tives and potentially forming apex organisations, farmers are able to have stronger influence in policy processes at local and national levels, significantly increase their negoti- ating powers, and more easily facilitate new access to domestic and international markets. Finally, in addition to linking up with national governments to foster a favourable market environment, farmers, with their combined bonding and bridging capital, are able to negotiate contracts and establish links with external organisations and international companies requiring raw or processed agricultural products (Herbel et al. 2012, Kawa and Kaitira 2007, Holloway et al. 1999, World Bank 2008).

\section{Land tenure and farmland security}

Availability of land is an important contributor to farm productivity and the capacity of farmers to expand and intensify production using technological innovation. Few of Nigeria's rural farmers cultivate lands obtained from their share of family holdings, but the vast majority depend on rentals and leases from communal or privately owned lands, and government. The major challenge for the latter, and bigger, group is that the lands can be taken from them at the shortest possible notice without any realistic hope of compensation or replacement, sometimes 
having to give way new plans by government or private owners to develop the land for other uses (Akinola 2006, ECA 2004, Place 2009).

In addition to the problem of land tenure, another major challenge confronting rural farmers in Nigeria is the security of cultivated farm lands, particularly with regard to the perennial and ever worsening conflict with nomadic herdsmen, called Bororos in Nigeria. Indeed, several farmers identified this as their major struggle for survival:

The marauding herdsmen and their cattle are the chief of our worries as farmers. They ravage our farms incessantly; some even harvest our cassava to feed their cattle! The cooperative strove hard to ward them off but to no avail and government has not been of much help on the matter, either (Farmer 93).

The herdsmen are a huge concern and we have done virtually everything possible to resolve the issue - from holding several meetings with the police, informing the Commissioner up to the Governor, all to no avail. Farming is now frustrating because of this (Farmer 94).

The main challenge that we have is the Fulani cattle rearers. They destroy our farm so much and we have become powerless against them because if you challenge them they threaten to kill us and inherit our farm. We have reported this to police station and nothing has been done so far (Farmer 205).

The challenge is the herdsmen that trouble us day and night by eating our crops (Farmer 92).

The herdsmen are another huge challenge; they and their cattle consume both maize and cassava crops. We farm settlers have discussed the matter, still to no avail (Farmer 91).

In consonance with the sentiments of farmers outlined above, the farmer-herdsmen conflict has been recognised by several scholars as the most preponderant resource conflict in Nigeria, with far-reaching implications for rural development, community cohesion and farmers' prosperity (Adisa 2012, Fasona and Omotosho 2005). This conflict is especially pronounced between the months of June and September, at the peak of the rainy season, when cattle herding activities by nomadic pastoralists coincide with arable crop production.

Destruction of crops by herdsmen is a major factor militating against farm productivity and sales, which invariably weakens the capacity and hope of farmers to benefit from adoption of innovative inputs, as well as hinder progressive up-scaling and intensification. Conversely, nomadic pastoralists depend on the health and productivity of their cattle for survival and prosperity, and they sometimes struggle with lack of adequate grazing land and difficulty in keeping cattle off fragmented crop lands in their grazing routes.

Thus, the onus is on government, at local and national levels, to mediate between the two groups and proffer lasting solutions by catering for the security of crops and farmlands on the one hand, and meeting the resource needs of pastoralists on the other, since both groups are bona fide citizens engaged in legitimate economic activities. The 
current approach of the government appears to lack the urgency and commitment the situation requires:

The Bororo problem is a national problem, and the current approach of the state government is to have dialogue with Yoruba host communities and Bororo people, together with security agencies. Traditional rulers were also invited and briefed on how they can mediate and control the situation. Finally, government has made plans to build grazing reserves as a way of finally solving the problem. The herdsmen were happy with that. So we've asked local governments to provide 50 ha each for grazing reserves. We have had few responses from some of the local government. There is plan to charge the herdsmen for use of these grazing reserves. There is land available at Ibarapa North for grazing reserves, but that effort was at the instance of the federal government, not the state. For the state government plans, we are waiting for the local government to respond to the request for land, and after that we hope the grazing reserves can take off next year (2013) (Director, Oyo State Ministry of Agriculture and Water Resources, Ibadan, Nigeria).

At the time of writing, about 18 months after the interview, there has been no concrete progress on the plan of Oyo State government to build grazing reserves. The apparent struggle of the state government to obtain land for grazing is not consistent with the provisions of the Nigerian Land Use Act (1978), which puts the control of most lands in the hand of the state governors, with only limited control in the hand of local government executives. It is difficult to avoid the suggestion that lack of political will and resource commitment on the part of governments is not unconnected with the apparent invisibility of the rural poor, and their weak influence in the political process leading to policy formulations.

The contributions of government, regarding creation of favourable institutional conditions for the prosperity of rural farmers, are not limited to matters of land tenure and farmland security. The following section will focus attention on equally important issues relating to the improvement and reform of research and extension services, provision of vital infrastructure and amenities, and increased commitment in terms of budgetary allocations and management.

\section{The role of governments}

In the light of the foregoing discussions about in-depth knowledge about technological innovations, access to value added inputs and processing facilities, and the crucial importance of access to markets, the contributions of government is essential for farmers' realisation of the goal of increasing productivity and maximising profit. The role of government can be classified into three main categories: 1) reforming and improving extension services; 2) expanding access to input and output markets; and 3) provision and rehabilitation of essential physical infrastructure. 
Reforming and improving research and extension service In Nigeria, before independence when the different parts were ruled by regional government, the government of the Western Region launched, in the 1950s, a major programme of farm settlements, using the model of the Israeli Moshavim. Lands were procured and several settlements were founded in various parts of the western region. Extension services for resident farmers were provided by resident farm managers, trained and paid by the regional governments. Currently, extension services for farm settlers and other rural farmers are provided by Agricultural Development Projects (ADPs) in various states and regions of the country. In Oyo State, the location of this study, the ADP is the Oyo State Agricultural Development Programme (OYSADEP). According to a senior officer,

OYSADEP started in 1985, and then it covered only Oyo North, and went state-wide in 1989. It was the initiative of the World Bank, with $60 \%$ funding by the World Bank, and embraced and supported by the federal military government and Oyo State government with 10\% and 30\% funding respectively (Principal Officer, OYSADEP, Ibadan, Nigeria).

It is instructive that the agency saddled with the responsibility of providing vital extension services to rural farmers was started with most of the funding from the World Bank, with the remaining $40 \%$ contributed by the Nigerian national and state governments. The World Bank support ended in 1996, and the federal government has stopped, rather than increased, its contribution since 1997. The viability of the extension agency seems to have been weakened by apparent dependency on external funders. From 1997, the entire funding of OYSADEP has been the sole responsibility of the Oyo State government. Inevitably, funding became unstable and the work-force was cut by $50 \%$ :

\footnotetext{
The major setback we had in terms of staffers came during the military regime of one Col. Usman (1997/1998). He asked the management to reduce the work force by 50\%... As of August 2012, we have 483 staffers in OYSADEP. When the ADP was full-fledged, in the days when we had the support of the World Bank - which stopped in 1996 - we had many more staff. In the early 1990s, we had more than 1000 staff members ... The FAO (Food and Agricultural Association) recommendation is one extension agent to 800 farm families. With current staffing, it has dwindled to one extension agent to about 3000 or 4000 farm families (Principal Officer, OYSADEP, Ibadan, Nigeria)
}

Thus, funding and staffing is a major problem for the state-owned extension agency, significantly hindering their capacity to reach out to rural farmers in the state. A 2001 survey in the state show that there are 415035 farm families in the state, but with current staffing, the agency is only capable of reaching about 50000 farm families.

The lack of funding also hinders capacity building and continuous training of extension workers and the ability to respond to changing needs of farmers. Traditional 
extension services have typically focused on educating farmers about the benefits of innovative inputs and machinery and demonstrating how they can use them. In Nigeria, there has been little attention given to educating farmers about postharvest innovations, especially with regard to processing and storage of raw farm products, which, as highlighted in the foregoing are essential for enhancing market value of products. Moreover, and partly because of heavy dependence on external knowledge, there seems to be a lack of clear and focused policy guidelines for the development and management of agricultural extension in Nigeria (Ammani et al. 2011).

Agricultural research institutes, which work closely with the ADPs, have also faced the challenge of inadequate funding:

Remember, in the history of IITA (International Institute of Tropical Agriculture), it was actually founded (in 1967) by Rockefeller Foundation and Ford Foundation. For the first 20 years the federal government gave only land, no money. Abdusallam (1998/99) was the first head of state to pay some money, then Obasanjo (1999-2007) did really well in terms of funding. After Obasanjo (2007), we have not received any funding again from the federal government (Cassava expert, IITA).

In view of the multi-dimensional and dynamic nature of farmers' requirements, there is need for government to undertake a reform and improvement of extension services. In addition to hiring enough staff, there is need for further training of extension workers, so they can provide additional training and demonstration for farmers, preferably farmer groups and cooperatives, on use of innovative processing facilities, packaging and quality control, information about domestic and international markets, and training support (for farmer groups) on risk control and financial management. Moreover, perfor- mance evaluation of extension agencies should be linked to their contributions, in quantifiable terms, to increased economic prosperity of rural farmers.

\section{Expanding access to input and output markets}

Awareness of technological innovations does not necessarily translate into access in terms of procure- ment from the input market. Periodically, governments have engaged in small-scale distribution of subsidised inputs like fertilisers and high yield seeds, and even with that, a lot of farmers complain about failure to benefit or obtain promised subsidies, after efforts to buy forms and register with the appropriate agencies. In general, the majority of farmers obtain their inputs through private agro input dealers, who visit villages from time to time, and also bring inputs for sales on market days. Farmers in remote places and those with poor transport links struggle to obtain inputs as and when needed. Agro dealers have expressed the view that the problem of farmers' inadequate access to innovations is partly due to the failure of the government to incorporate technology sellers into their agricultural policy and plans: 
Until now the policy and programmes of government on agriculture have never yielded desired results not just because of inadequate funding or lack of sincerity, but because they missed out very important people in the value chain, which are the technology sellers. More often than not when government say they've provided inputs, they don't get to farmers (Chairman, Agric Input Dealers' Association, Ibadan, Southwest Zone).

Prior to 2002, individual agro input dealers scattered across Nigerian states and major cities conducted their business alone, without any formal link or collaboration with other agro dealers:

About 10 years ago, some donors came from US, especially USAID and Rockefeller Foundation. They came under the aegis of International Fertilizer Development Centre, which was linking up input dealers across the entire nation. They picked 4 states - Oyo, Kano, Bauchi and Federal Capital Territory. They funded and ran a programme for about three years during which input dealers in these states were linked together and trained, following which the association was inaugurated in the four zones - Oyo State Agric Input Dealers' Association, similarly for other three zones. The associations were left to run by themselves in about 2005/2006, but by them they had the necessary trainings and support to continue (Chairman, Agric Input Dealers Association, Ibadan, Southwest Zone).

This association of agro input dealers now pool their resources to organise joint publicity campaigns on radio and other media, and organise continuous technical trainings for members, including information on banned and restricted chemicals. They interact as a group with research institutes, who invite them for training and seminars. In addition, they employ 'a strategy of dealing with farmer groups - sometimes according to the crops they specialise in - maize, cassava, etc. When we have new information we notify the farmer groups, and arrange meetings and interactions between these groups' representatives and the main suppliers' (Chairman, Agric Input Dealers' Association 2012).

From the foregoing, it is clear that agro input dealers are important key stakeholders that should be included in the strategy of government to expand farmers' access to input markets. The government contribution can be in terms of linking them up with input manufacturers and extension agencies, sponsoring or subsidising trainings, and employing them for faster and more efficient distribution of subsidised inputs.

In addition to input markets, the access of farmers to domestic and international markets for sale of their produce is essential for farmers' economic prosperity and capacity to adopt innovations and intensify and expand production (Komarwa et al. 2002). Researchers have investigated a number of innovative approaches used in developing countries to expand access of small-scale farmers to output markets. These include: 1) commodity exchange; 2) contract farming; and 3) fair trade and organic schemes (Woodend 2003, Coulter et al. 1999). The vital contribution of government here, acting singly

or in partnership with NGOs and international agencies, will be to facilitate and coordinate the arrangements, and provide necessary support for small-holder farmers.

Commodity exchange is essentially a formal meeting point between producers and buyers where sellers, through their brokers, register the quantity, quality and location of their products, and buyers, also through their brokers, bid for the commodities. In Zambia, this arrange- ment was facilitated by the World Food Programme, which also provided subsidised quality testing services for the farmers, as well as established a network of certified warehouses across the country where farmers can sell when the prices are higher (Herbel et al. 2012). The main advantage of commodity exchange is that it opens up and guarantees new output market for farmers. The Nigerian government can adopt this approach by facili- tating commodity exchange between producer farmers and buyers, providing subsidised quality control services, and providing storage facilities across the country where farmers or farmer groups preferably, can store their produce for a token and sell when the prices are higher.

Contract farming entails advance agreements between producer farmers and food companies, including large supermarket chains, which are growing rapidly in cities in developing countries. This arrangement works best with cooperatives and farmer groups, as the cost of transaction and the risk of inadequate and irregular supply is much higher with individual farmers scattered across the country (Coulter et al. 1999). In addition to guaranteeing access to new markets for their farm produce, other advantages of contract farming include access to input and innova- tions often supplied by the 
contracting food company/ supermarket, and price-risk reduction (Eaton and Shepherd 2001). Government can contribute by providing incentives for agri-business and food companies to form partnership with small-scale farmers, and also help organise farmers into producer groups

Fair-trade arrangements provide farmers with unique and lucrative opportunities to link up with international markets. Under this scheme, farmer groups and coopera- tives sign contractual agreements with international companies producing particular types of agro-allied products. In Bhutan, where this approach has been employed with good success, farmers' cooperatives partner with private companies providing certification and labelling services to enhance the quality of their products (Herbel et al. 2012). In Nigeria, similar arrangements can be facilitated and/or supported by government, with possible participations of NGOs, international organisations and other stakeholders.

Provision and rehabilitation of essential infrastructure The problem of derelict infrastructure is at the heart of multiple challenges faced by rural farmers in Nigeria. The limited investment in public infrastructure is skewed in favour of urban areas, and rural development has lagged behind in terms of governmental commitment and budgetary allocations. The main areas of concern that should command the priority attention of government for rural dwellers include: 1) provision and rehabilitation of road networks; 2) rural electrification; 3) provision of storage facilities; and 4) provision of irrigation infrastructure.

There is recognition on the part of government that the worsening conditions of essential infrastructure and amenities pose a serious challenge agricultural productivity and food security and is a major factor influencing increasing rate of rural-urban migration, of youths especially. In spite of this recognition, there has been little done in real terms to deal with the problem with adequate commitment and consistency:

Plans have been concluded to rehabilitate the roads by grading them. Government want to make the farm settlements more attractive. Work has begun at Ijaye farm settlement. We are also focusing on improving the electricity infrastructure. The plan is to start working on the roads during the coming dry season. Government has committed funds on paper for that, but the funds have not been released. Contracts for electricity infrastructure for some of the settlements were awarded by the federal government years ago, but the contract was abandoned. The plan now is to restart those projects (Director, Oyo State Ministry of Agriculture, Ibadan).

It appears that past efforts of government on rural infrastructure have been largely characterised by abandoned projects and unfulfilled promises and farmers are left frustrated without much needed support, exemplified by the following comment:

The challenges I face is that there is no help. Government should be assisting us in giving out money to us to use in farming and then we can return the money that was giving to us. There are no amenities, we do not have electricity, and as you can see there is no good road nor is there borehole (for potable water). Transportation is another main challenge, after harvesting our farm produce we do not have readily available transport for us to transport our farm produce to the market (Farmer 218).

Poor infrastructure and low agricultural development have been described as a vicious cycle in which low productivity and income of rural farmers is used to justify absent or inadequate investment in rural infrastructure, and the lack of investment in infrastructure in turn aggravates rural poverty (FAO 2008). Thus, a number of countries have adopted an integrated approach to infrastructural development in which, for example, an infrastructural development programme incorporates provision of roads, electricity and water supply, all essential for, and interlinked with different areas of farmers' economic activities. In Nigeria, an integrated approach with an infrastructure 'bundle' of roads, water, electricity, storage and irrigation network, will not only significantly improve the economic productivity of farmers, but will also enable them to take ownership and make financial and practical contribution for the maintenance of the

bundled infrastructure. These infrastructural projects can be undertaken with a public-private partnership, and new revenues generated from payment of users can be used for initiation of new projects. 


\section{Towards a new cooperative model}

The foregoing sections have focused on discussion of various institutional factors identified by farmers and key stakeholders as key challenges to the capacity of rural farmers to gain optimum benefit from adoption of innova- tions, in terms of increasing value-added production and profit. For all of the institutional factors examined, the recurring theme is that, in order for small scale rural farmers to overcome these challenges, they stand a better chance if they come together in groups, rather than as individuals. With regard to access to credit, for example, it was observed, from the views of commercial and public-funded banks, that formal cooperatives have better chances of obtaining loans as they can provide collective collateral on behalf of members, authenticate members' farming activities, and have better structure in place to enforce loan repayments.

Similarly, formal cooperatives are better positioned to overcome, or at least mitigate, the economies of scale and high transaction costs associated with procurement of innovative inputs and viability of processing machinery and enterprise. With respect to market competitiveness, cooperatives are able to gain better access to new markets by bridging social capital with apex organisations, and linking social capital with domestic and foreign food companies and supermarket chains. On the issue of land tenure, farmer groups are more able to access land on collective leases from government or community owners, and they are also able to exercise more effective influence on government policies relating to resolution of resource conflict and farm land security. Moreover, the effectiveness of government contribution and support, say with regard to provision of essential infrastructure, depends on the strength and viability of organised farmer groups.

However, the traditional forms of farmers' cooperatives do not seem to adequately satisfy the multi-faceted and dynamic needs of rural farmers. Many rural farmers rely on their informal network of friends and family members to meet their needs on credit, input procurement and marketing of their produce. Some are lapsed cooperative members, having discontinued member- ship on account of unrealised expectations. Many current members have also expressed dissatisfaction or disappointment with issues within the cooperatives:

Presently, we need money to assist us. Our cooperative is dead because there is no money, the government promised to assist us and raise the association back. Therefore, we are seriously relying on the government to revive our cooperative back (Farmer 201). 
I have not received any benefit in the cooperative. Our challenge is the government, the government has promised to give us money but they have not fulfilled their bargain. They even collected money from us to buy forms but until now, nothing has come forth (Farmer 202).

Well, the benefit of cooperative is that last year we were loaned some money but not this year due to the defaulters amidst us (Farmer 221

My membership of the cooperative has not been of any benefit whatsoever. Since there is no help whatsoever and money is lacking, how can we make headway? (Farmer 225).

My advice for the improvement of the cooperative is that our representatives speak to and implore the government to help us (Farmer 26).

The advice to the cooperative is to implore government to pay more attention to the plight of farmers, and help bolster farming. The problem is that the money released by the government hardly gets to the farmers on the farm and this is because certain people in the town (businesspersons, government workers) falsely introduce themselves as farmers to the government representatives and thus intercept the funds. My advice is for government to ensure its representatives do not stay in town but also come down to the farms to see things for themselves (Farmer 27).

The above comments underline the fact that many cooperatives are not viable or sufficient, and the underperformance of farmers' cooperatives is linked, among others, to almost total reliance on government, open and unrestricted membership, vaguely defined property rights, lack of diversification and engagement in processing and other value addition activities, lack or weakness of collective action on exploring new marketing opportunities, and break in trust exemplified by incidences of loan defaults by members. In essence, the cooperatives seem to have failed or underperformed in the very areas in which they have unique potentials to excel, compared with small- scale individual enterprises.

Several scholars have suggested that farmers' cooperatives need to evolve from a traditional structure of operation and old organisational models in order to reposition and innovate to embrace new challenges and opportunities inherent in contemporary institutional and market environments (Stefanson and Fulton 1997, Chaddad and Cook 2004, Iliopolous 2005). The main features of new cooperative models identified by these researchers include: 1) involvement in valueadded processing beyond the traditional focus on production of raw goods; 2) generation of investment capital from members purchase of shares/equities for delivery rights, at once guaranteeing supply of raw products and also generating capital for processing machinery and logistics; 3) clearly defined and restricted membership, partly to mitigate the problems of the 'free rider' who does not join but seeks to benefit from cooperative activities; 4) distribution of ownership rights according to proportionality of members' usage/patronage, and not blanket equal distribution for all; and 5) clearly defined property rights that are secure and tradable.

A proposed new cooperative model for Nigerian rural farmers should incorporate most or all of the highlighted features. Table 1 is based on critical reflection on the data and information emanating from farmers and key stakeholders in this investigation, in addition to critical issues that have been discussed in the literature. It provides a summary of what this new model might look like in practice, and how it can, compared with traditional models, optimally benefit from a combination of product and institutional innovations. 
Table 7.1: A new cooperative model for Nigerian farmers

\section{Features}

\section{Description}

Well defined membership \&

commitment

Membership should be clearly defined in terms of ownership right and explicit commitment to contribute revenue by buying equities.

Multipurpose support

services

Performance oriented

governmental support

Integrated value addition

Continuous expansion and diversification

Revenue and earnings
Unlike traditional cooperatives, which are often limited by focus on one or few services for members, the new cooperative model should incorporate a multi-faceted approach to support services for members, in terms of loan disbursement, input procurement \& collective marketing activities, among others.

To forestall overdependence, governmental support should incremental, and based on cooperative performance. Also, supports are preferably provided in kind, rather than cash, in terms of subsidised inputs, processing machinery, storage facilities, information and training, etc.

The new cooperative model should not be limited to production, but incorporate value addition activities like processing, quality control and packaging that significantly increase the market value of products and in turn the profits and earnings of the cooperative and individual members.

The new cooperative does not have to start big to be viable, especially in the rural Nigerian context. With room for continuous growth, the cooperative can begin with value added production and improved marketing of single or few goods, to value added processing and packaging, to investments in production, processing and marketing of multiple agricultural goods.

In addition to members' direct contributions via equities, the new cooperative can more easily access credit from financial institutions, compared with traditional ones. Also, proportiona sharing of profits suitably rewards stronger members and also provides incentive for weaker coop members.

\section{Constraints/further remarks}

The cooperative may require a minimum number of members and minimum and regular supply of raw goods to be viable.

Integrated support for members strengthens their production capacity and ability to fulfil financial obligations to the cooperative. However, this requires more resources in terms of logistics and practical management.

There is a risk that weakly performing cooperatives may be left behind in terms of performance-based support. Support for such should be to fix the weaknesses, perhaps in terms of committed membership or market access, but not by pouring in subsidies and cash that will not yield fruits.

Production should also entail value added activities in terms highyielding and high quality (nutritious) varieties. Packaging and labelling may be constrained by high transaction costs and economies of scale, but this can be mitigated by coordinating with apex bodies.

Progressive growth of the cooperative will be constrained by the pace of cooperative performance in production and profit, and the capacity of leaders and members in terms of training and knowledge in technical operations and financial and risk managements.

There is a risk of stratification of members according to earnings, but this can be mitigated by designing a plan that allows underinvested members to increase their equities as and when capable. 



\section{Conclusion}

This study shows that institutional factors can significantly hinder or foster successful uptake of technological innovations. These factors include the challenges associated with the performance and accessibility of credit institutions, the problem of restricted access to existing markets and lack of opportunities in new markets, availability and performance of value-added processing and packaging, the challenge of insecure land tenure and resource conflicts with nomadic herdsmen, and lack of effective support from government in terms of essential infrastructure, funding and capacity building. These challenges, it is observed, are better addressed together, in bundles, as weaknesses found in one institution, say, can significantly hinder the performance of others.

It is suggested that, in order to effectively surmount or mitigate these challenges, a new model of farmers' cooperative should be adopted as the nucleus of an integrated product-institutional innovations system that can success- fully facilitate economic empowerment of rural farmers, justify continuing investment in rural infrastructure, resolve food security, and make a significant contribution to the overall well-being and development of the nation.

\section{References}

Abdulrahaman, A. and Kolawole, O. (2006), Traditional preparations and uses of maize in Nigeria. Ethnobotanical Leaflets August: 219-227.

Adejobi, O. and Atobatele, J. (2008), An analysis of loan delinquency among small scale farmers in Southwestern Nigeria: application of logit and loan performance indices. East African Agricultural and Forestry Journal 74(3): 149-157.

Adisa, R.S. (2012), Land use conflict between farmers and herdsmen: Implication for agricultural and rural development in Nigeria. In: Rural Development: Contemporary Issues and Practices. s.1.: In Tech (Online), pp. 99-118.

Akinola, S.R. (2006), Land use decree, forest administration and land use decree in Nigeria. Accra, Ghana: s.n.

Ammani, A.A., Sani, B.M., Kura, H.N. and Hussaini, Y. (2011), An assessment of agricultural extension services in irrigation schemes under RBDAs' control in Nigeria: The case of Kano River irrigation project. Journal of Agricultural Extension and Rural Development 3(1): 13-18.

Ayanda, I. and Ogunsekan, O. (2012), Farmers' perception of loans obtained from Bank of Agriculture, Ogun State, Nigeria. Journal of Agricultural Science 3(1): 21-27.

Ayodele, O.S., Obafemi, F.N. and Ebong, F.S., (2013), Challenges facing the achievement of the Nigeria vision 20:2020. Global Advanced Research Journal of Social Science 2(7): 143-157.

Badiru, I.O. (2010. Review of small farmer access to agricultural credit in Nigeria. Abuja: International Food Policy Research Institute.

Bah, M. et al., (2003), Changing rural-urban linkages in Mali, Nigeria and Tanzania. Environment and Urbanisation 15(1): 13-24.

Chaddad, F.R. and Cook, M.L., (2004), Understanding new cooperative model: An ownership control rights typology. Review of Agricultural Economics 26(3): 248-260.

Coulter, J., Goodland, A., Tallontire, A. and Stringfellow, R., (1999), Marrying farmer cooperation and contract farming for service provision in a liberalising sub-Saharan Africa. Natural Resource Perspectives November, Issue 48: 1-4.

Doner, R.F., (2010), Introduction: explaining institutional innovation. In: R.F. Doner (ed.), Explaining institutional innovation: case studies from Latin America and East Asia. pp. 9-18. New York: Social Science Research Council.

Eaton, C. and Shepherd, A.W. (2001), Contract farming. Partnerships for growth. Rome: Food and Agricultural Organisation.

ECA (Economic Commission for Africa) (2004), Land tenure systems and their impacts on economic security and sustainable development in Africa. Addis Ababa: Economic Commission for Africa.

Eze, C.C. et al., (2010), Agricultural financing policies and rural development in Nigeria. Edinburgh: Agricultural Economics Society.

Fan, Q. and Zeng, D.Z. (2009), Introduction and summary. In:

Q. Fan, et al. (eds.), Innovation for development and the role of government - A perspective from East Asia and Pacific Region. pp. 1-6. Washington DC: World Bank. 
FAO (Food and Agriculture Organization) (2008), Market oriented agricultural infrastructure: Appraisal of public-private partnerships. Rome: Food and Agriculture Organization of the United Nations.

Fasona, M.J. and Omojola, A. (2005), Climate change, human security and communal clashes in Nigeria. Oslo: International Workshop on Human Security and Climate Change.

Fleming, K. (2005), Value-added strategies - Taking agricultural products to the next level. AgriBusiness February: 12.

Food and Fertilizer Technology Centre (2004), Making farm credit work for the small-scale farmers. [Online] Available at: http://www.agnet.org/library.php?func=view\&id=20110 725172105\&type_id=3 [Accessed 10 October 2013].

Francis, P. (1987), Land tenure system and agricultural innovations: The case of alley farming in Nigeria. Land Use Policy 4: 305-319.

Grabowski, R. (1991), Agricultural development and institutional innovation: A view of early Japan. Journal of Asian Economics 2(2): 249-263.

Hartley, S. and Johnson, H. (2014), Learning to cooperate: Youth engagement with the cooperative revival in Africa. European Journal of Development Research 26(1): 55-70.

Herbel, D., Crowley, E., Ourabah-Haddad, N. and Lee, M. (2012), Good practices in building innovative rural institutions to increase food security. Rome: Food and Agricultural Organisation of the United Nations.

Hinsz, V.B. and Nickell, G.S. (2004), Positive reactions to working in groups. Group Dynamics: Theory, Research \& Practice 8(4): 253-264.

Holloway, G., Nicholson, C. and Delgado, C. (1999), Agro-industrialization through institutional innovations: transaction costs, cooperatives and milk market development in the Ethiopian Highlands. Washington, D.C.: International Food Policy Research Institute.

Huppi, M. and Feder, G. (1989), The role of groups and credit cooperatives in rural lending. Washington, DC: World Bank. IFAD (International Fund for Agricultural Development) (2012), Enabling poor rural people to overcome poverty in Nigeria.

Rome: International Fund for Agricultural Development.

Iliopoulos, C. (2005), New generation cooperatives: the potential of an innovative institutional arrangement for Mediterranean food supply chains. NEW MEDIT 1: 14-20.

Johnson, H. (2007), Communities of practice and international development. Progress in Development Studies 7(4): 277290.

Kassali, R., Ayanwale, A.B., Idowu, E.O. and Williams, S.B. (2012), Effect of rural transportation system on agricultural productivity in Oyo State, Nigeria. Journal of Agriculture and Rural Development in the Tropics and Subtropics 113(1): $13-19$.

Kawa, I.H. and Kaitira, L.M. (2007), Enhancing smallholder farmers market competitiveness in Tanzania, New York: Cornell University.

Knipscheer, H. et al. (2007), Opportunities in the industrial cassava market in Nigeria. Ibadan: International Institute for Tropical Agriculture.

Komarwa, P., Ezedinma, C., Adekunle, A. and Makinde, K. (2002), Promoting market-led agricultural transfer and commercialisation in Nigeria. Ibadan: International Institute of Tropical Agriculture.

Langyintuo, A.S. and Mungoma, C. (2008), The effects of household wealth on the adoption of improved maize varieties in Zambia. Food Policy 33: 550-559.

Marenya, P.P. and Barrett, C.B. (2007), Household-level determinants of adoption of improved natural resource management amog small holder farmers in Western Kenya. Food Policy 32: 515-536.

Moser, C.M. and Barrett, C.B. (2003), The disappointing dynamics of a yield-increasing, low- external input technology: The case of SRI in Madagasgar. Agricultural Systems 76: 1085-1100.

Okojie, C. et al. (2010), Institutional environment and access to microfinance by self-employed women in rural areas of Edo State. Abuja: International Food Policy Research Institute. 
Oyedepo, S.O. (2012), Energy and sustainable development in Nigeria. Energy, Sustainability and Society 2(15): 1-17. Place, F. (2009), Land tenure and agricultural productivity in Africa: A comparative analysis of the economic literature and recent policy strategies and reforms. World Development 37(8): 1326-1336.

Reardon, T. and Vosti, S.A. (1997), Poverty-environment links in rural areas of developing countries. In: S.A. Reardon and T. Vosti (eds.), Sustainability, growth and poverty alleviation: A policy and agroeocological perspective. pp. 4765.Baltimore, Maryland: John Hopkins.

Ruttan, V.W. (2001), Technology, growth, and development: an induced innovation perspective. New York: Oxford University Press.

Sanni, L. et al. (2005), Value addition to cassava in Africa: Challenges and opportunities. African Crop Science Conference Proceedings 7: 583-590.

Stefanson, B. and Fulton, M. (1997), New generation cooperatives: responding to changes in agriculture. Saskatoon: University of Saskatchewan. 
Stefanson, B. and Fulton, M. (1997), New generation cooperatives: Responding to changes in agriculture. Saskatoon: University of Saskatchewan.

Warner, A.M. (2001), Small and medium sized enterprises and economic creativity. In: R. Ricupero (ed.) Improving the competitiveness of SMEs in developing countries: The role of finance to enhance enterprise development. pp. 61-75. New York and Geneva: United Nations.

White, D.S., Labarta, R.A. and Leguia, E.J. (2005), Technology adoption by resource poor farmers: considering the implications of peak-season labour costs. Agricultural Systems 85: 183-201.

Woodend, J.J. (2003), Potential of contract farming as a mechanisation for the commercialisation of small-holder agriculture: The Zimbabwe case study. Rome: Food and Agricultural Organisation.

World Bank (2008), Supporting small-holder competitiveness through institutional innovations. In: Agriculture for development. pp. 138-157 Washington, DC: The World Bank. 